\author{
Adam SZWEDA \\ Instytut Historii i Archiwistyki UMK \\ Sobiesław SZYBKOWSKI \\ Instytut Historii Uniwersytetu Gdańskiego
}

\title{
Kilka słów o pieczęci biskupa włocławskiego Jana Pelli z Niewiesza przy dokumencie pokoju mełneńskiego z 1422 r.
}

\begin{abstract}
Zarys treści: Celem niniejszego przyczynku jest przedstawienie perypetii związanych z przywieszeniem pieczęci biskupa włocławskiego Jana Pelli z Niewiesza do głównego dokumentu pokoju mełneńskiego strony polskiej z 1422 r. Mimo że opieczętowany dokument tego traktatu został przekazany stronie krzyżackiej na zjeździe w Wielonie w kwietniu 1423 r., brakowało tam pieczęci biskupa Jana, jako jednego z polskich gwarantów pokoju. Znalazła się ona tam dopiero 14 IV 1426. Jako aneksy zostały opublikowane dwa źródła dotyczące przeprowadzenia tej czynności: instrument notarialny z 14 kwietnia oraz list komtura toruńskiego Henryka Marschalka do wielkiego mistrza Pawła von Rusdorfa z 15 IV 1426.
\end{abstract}

\begin{abstract}
The purpose of the article is to present trials and tribulations with the attachment of the seal of Bishop of Włocławek Jan Pella of Niewiesz to the main Polish document of the 1422 Mełno Peace. Despite the fact that the sealed document of the treaty was handed over to the Teutonic Knights at an assembly at Wielona in April of 1423, there was no seal of Bishop Jan, who was one of the Polish guarantors of the peace. It was not until 14 April 1426 that the seal was put to the document. The article is supplemented by an edition of two sources related to the attachment of the bishop's seal: a notary's instrument of 14 April, and a letter of Torun Commander Henryk Marschalk to the Grand Master of the Teutonic Order Paul von Rusdorf of 15 April 1426.
\end{abstract}

Słowa kluczowe: pieczęć, traktaty pokojowe, Królestwo Polskie, zakon krzyżacki, biskupi włocławscy

Keywords: seal, peace treatises, Kingdom of Poland, Teutonic Order, bishops of Włocławek

Jednym z gwarantów polsko-krzyżackiego traktatu pokojowego zawartego 27 IX 1422 był biskup włocławski Jan Pella z Niewiesza h. Pomian ${ }^{1}$. Przy głównym polskim dokumencie tego pokoju przekazanym stronie krzyżackiej na zjeździe w litewskiej Wielonie (9-18 V 1423)² znajduje się również jego dobrze zachowana pieczęć $c^{3}$. Nie było jej wszakże przy wspomnianym dokumencie podczas jego przekazania (co oznaczało, że delegacja polska nie przywiozła ze sobą tłoka biskupiej pieczęci), a stronie zakonnej przyszło czekać na jej przywieszenie jeszcze prawie trzy lata. Dzieje zabiegów dotyczących

\footnotetext{
${ }^{1}$ Dokumenty strony polsko-litewskiej pokoju metneńskiego z 1422 roku, wyd. P. Nowak, P. Pokora, Poznań 2004, s. 10, w dokumencie głównym strony polskiej ujęto go jako piątego spośród polskich gwarantów, po książętach mazowieckich Januszu I i Siemowicie IV oraz arcybiskupie lwowskim i biskupie krakowskim.

2 Tamże, s. VIII; K. Neitmann, Die Staatsverträge des Deutschen Ordens in Preussen 1230-1449. Studien zur Diplomatie eines spätmittelalterlichen deutschen Teritorialstaates, Köln-Wien 1986, s. 183-184; A. Szweda, Organizacja i technika dyplomacji polskiej w stosunkach z zakonem krzyżackim w Prusach w latach 1386-1454, Toruń 2009, s. 302, 393-394.

3 Dokumenty strony polsko-litewskiej, s. 10, 25-26 (tu jej bardzo szczegółowy opis, co zwalnia nas z jego powtarzania).
} 
uzupełnienia brakującej pieczęci biskupa Jana oraz ostatecznego załatwienia tej kwestii pokazują niewątpliwie, jak dużą wagę przykładała strona krzyżacka do pozyskania pieczęci wszystkich polskich gwarantów układu pokojowego, stanowiąc jednocześnie interesujący przyczynek do historii polsko-krzyżackich relacji dyplomatycznych z tego okresu. Finał tego procesu dokumentują nadto dwa niewydane dotąd źródła archiwalne, które publikujemy w całości w aneksach.

Problemy dotyczące skompletowania pieczęci gwarantów traktatu pokojowego zawartego na jeziorem Mełno pojawiły się już na początku procedury jego spisania, ratyfikacji i wzajemnej wymiany dokumentów. W preliminariach ustalono bowiem, że nastąpi to już 2 XI 1422 na zjeździe pełnomocników układających się stron w kujawskim Gniewkowie. Pełnomocnicy ci powinni mieć przy sobie pieczęcie majestatowe obu władców, a także „prałatów, baronów i miast” (w przypadku strony polsko-litewskiej) oraz większe pieczęcie mistrza, ,jego prałatów i komturów”, wraz z pieczęciami miast i rycerzy (terrigenarum), wybranych przez negocjatorów drugiej strony (w przypadku strony krzyżackiej) i nimi na miejscu uwierzytelnić dokumenty główne 4 . Do spisania i przekazania dokumentów podczas tego spotkania jednak nie doszło, strona krzyżacka nie zdążyła bowiem zgromadzić wszystkich potrzebnych pieczęci - dokonała tego natomiast (jak się jednak okaże w niepełnym zakresie) strona polska. Reprezentanci Władysława Jagiełły przywieźli do Gniewkowa pieczęcie majestatowe swego mocodawcy, wielkiego księcia Witolda oraz polskich biskupów, panów i miast ${ }^{5}$. Kolejny termin finalizacji interesującej nas procedury został wyznaczony dopiero podczas pobytu zakonnej legacji u Witolda w styczniu 1423 r., kiedy to uzgodniono, że dojdzie do tego na zjeździe króla, wielkiego księcia i wielkiego mistrza w Wielonie, w kwietniu. Na spotkaniu tym doszło istotnie do ratyfikacji, spisania i wymiany opieczętowanych dokumentów pokojowych. Jak się jednak okazało, brakowało przy nich pieczęci istotnych gwarantów. Przy dokumencie polskim nie znalazły się bowiem pieczęcie arcybiskupa gnieźnieńskiego i biskupa włocławskiego, przy krzyżackim natomiast arcybiskupa ryskiego i biskupa dorpackiego ${ }^{6}$. $\mathrm{Na}$ brak pieczęci arcybiskupa gnieźnieńskiego wpływ miały przyczyny dość skomplikowanej natury. W grudniu 1422 r. zmarł prymas Mikołaj Trąba. Wybór jego następcy, którym został dotychczasowy biskup krakowski i podkanclerzy Królestwa Polskiego Wojciech Jastrzębiec, a następnie uzyskanie przezeń papieskiego zatwierdzenia przeciągnęły się aż do lipca następnego roku . Wobec zabiegów strony zakonnej zdecydowano, że nowy arcybiskup wystawi specjalny dokument dotyczący przestrzegania pokoju. Stało się to 13 VI 1424, kiedy odnośny dokument Jastrzębca został wystawiony i przekazany następnie do Prus ${ }^{8}$.

Sprawa przywieszenia brakującej pieczęci biskupa włocławskiego pozostawała natomiast w zawieszeniu aż do grudnia 1425 r. 13-17 grudnia w Grodnie odbył się zjazd króla Władysława Jagiełły i wielkiego księcia Witolda z wielkim mistrzem Pawłem von Rusdorfem. Obok innych spraw związanych ze stosunkami dwustronnymi poruszono tam również kwestie braku pieczęci niektórych gwarantów przy mełneńskich dokumentach pokojowych (z polskiej strony Jana Pelli, z krzyżackiej zaś arcybiskupa

${ }^{4}$ Tamże, s. 10 (kolumna I - dokument wstępny strony polsko-litewskiej); Die Staatsverträge des Deutschen Ordens in Preußen im 15. Jahrhundert, t. 1, wyd. E. Weise, wyd. 2, Marburg 1970, nr 152 (dokument wstępny strony zakonnej).

${ }^{5}$ K. Neitmann, Die Staatsverträge, s. 173-181; A. Szweda, Organizacja, s. 302, 393.

${ }^{6}$ A. Szweda, Organizacja, s. 302-303, 398.

7 Wiązało się to z wewnętrzną rozgrywką polityczną po stronie polskiej; zob.: A. Gąsiorowski, Arcybiskupi gnieźnieńscy w Polsce pierwszych Jagiellonów, Rocz. Hist., 59, 1993, s. 107; G. Lichończak-Nurek, Wojciech herbu Jastrzębiec, arcybiskup i mąż stanu (ok. 1362-1436), Kraków 1996, s. 95-99; A. Sperka, Zmiany na arcybiskupstwie gnieźnieńskim, biskupstwie krakowskim i urzędach kancelaryjnych na przełomie 1422/1423 roku, „Teki Krakowskie”, 5, 1997, s. 139-145; A. Szweda, Organizacja, s. 302-303. Wakat na polskim prymasostwie spowodował, że arcybiskup gnieźnieński w ogóle nie został wymieniony wśród gwarantów na dokumencie głównym. Chodziło jednak o kluczowego dostojnika, stąd procedurę jego przystąpienia do gwarancji przeprowadzono, gdy tylko było to możliwe. Należy jednak zauważyć, że Wojciech Jastrzębiec przywiesił do dokumentu głównego strony polskiej przekazanego Krzyżakom w Wielonie swoją pieczęć jako biskup krakowski; zob. Dokumenty strony polsko-litewskiej, s. 10, 24, 25.

${ }^{8}$ Codex diplomaticus Regni Poloniae et Magni Ducatus Lithuaniae, t. 4, wyd. M. Dogiel, Wilno 1764, nr 94; K. Neitmann, Die Staatsverträge, s. 188, 191; A. Szweda, Organizacja, s. 303, 395. Do przekazania arcybiskupiego dokumentu doszło być może podczas spotkania reprezentantów strony polskiej i krzyżackiej 1 IX 1424 w sprawie delimitacji granic w okolicach Jasińca, w którym Wojciech Jastrzębiec dowodnie uczestniczył; zob. A. Szweda, Organizacja, s. 396. 
ryskiego Henninga Scharpenberga oraz biskupa dorpackiego Teodoryka Reslera). Król zobowiązał się wówczas, że pieczęć Jana Pelli zostanie dostarczona do Torunia 14 IV $1426^{9}$.

Rozmowy grodzieńskie w przypadku pieczęci biskupa włocławskiego Jana znalazły swoje konsekwencje w terminie wówczas wyznaczonym ${ }^{10}$. Załatwienie tej istotnej dla strony krzyżackiej sprawy dokumentuje unikalne źródło, które w całości publikujemy w aneksie 1. Jest to instrument notarialny wystawiony przez notariusza publicznego autorytetu cesarskiego Stanisława Budkowica z Karnkowa 14 IV 1426 na zamku toruńskim ${ }^{11}$. Dowiadujemy się z niego, że w dniu jego wystawienia na zamek toruński przybył „pasowany rycerz króla Władysława” Piotr „Sbiluczsky”, aby przywiesić na polecenie swojego władcy pieczęć biskupa Pelli do dokumentu pokoju mełneńskiego. Po jej okazaniu proboszcz toruńskiego kościoła parafialnego św. Janów, doktor Andrzej Pfaffendorf, komtur toruński Henryk Marschalk oraz kapelan wielkiego mistrza Pawła von Rusdorfa - Grzegorz z Biskupca (von Bischofswerder) ${ }^{12}$, reprezentujący stronę krzyżacką, przedłożyli dokument traktatu. W dalszej kolejności wysłannik królewski osobiście dokonał przywieszenia biskupiej pieczęci do dokumentu pokojowego. Z tekstu nie wynika jasno, czy została ona przywieszona do przymocowanego już do karty pergaminowej paska pergaminowego, czy też zaopatrzoną wcześniej w pasek pergaminowy pieczęć umocowano do wycięcia $\mathrm{w}$ karcie $^{13}$. Analogii w tym względzie dostarcza jednak wspomniana wyżej sprawa uzupełnienia pieczęci arcybiskupa ryskiego i biskupa dorpackiego przy dokumencie zakonnym. W 1425 r. w Grodnie ustalono w tym względzie, że jeżeli imiona obu dostojników zostały wymienione w treści aktu, a paski pergaminu przeznaczone na ich pieczęcie są puste, wówczas zakon ma zadbać o dowieszenie ich pieczęci. W przeciwnym razie hierarchowie mieli wystawić osobne dokumenty ${ }^{14}$. Jan Pella był wymieniony w treści dokumentu, stąd można przyjąć, że do dokumentu dodano pasek pergaminu lub pozostawiono na niego miejsce $\mathrm{w}$ celu umocowania tam biskupiej pieczęci.

W instrumencie notarialnym obok samego opisu czynności znalazł się wszakże jeszcze niezwykle dokładny opis przywieszonej pieczęci. Dotyczył on nie tylko koloru właściwej pieczęci (,intus de cera rubea”), ale również miseczki (,ab extra naturali seu glauca”) oraz jej ikonografii. Należy przy tym podkreślić, że informacja o jej wyglądzie jest obszerna i dokładna oraz zadziwiająco zgodna z zachowanym oryginałem ${ }^{15}$. Odczytano również legendę, która nadto została zacytowana $\mathrm{w}$ instrumencie notarialnym. Jest to rozwiązanie typowe dla formularza tego typu dokumentów, a akt Stanisława Budkowica z Karnkowa spełnia wszelkie wymogi stawiane w tym względzie wytworom notariuszy przez prawo kanoniczne ${ }^{16}$. Wnikliwy opis pieczęci był normą przy transumowaniu dokumentów w formie instrumentu notarialnego ${ }^{17}$. Sięgnięcie po taką formę udokumentowania przekazania pieczęci dowodzi, że osobom zaangażowanym $\mathrm{w}$ tę sprawę zależało na jak najpełniejszym i wiarygodnym jej przedstawieniu. Właściwą część instrumentu notarialnego kończy wykaz świadków czynności, przy której byli

9 A. Szweda, Organizacja, s. 303, 398.

10 Tamże.

${ }^{11}$ Zob. aneks 1 .

${ }^{12}$ Identyfikacja osób występujących w instrumencie notarialnym znajduje się w przypisach tekstowych do edycji, wyjątek czynimy tylko dla posła królewskiego (zob. niżej). Skomentować jedynie wypada godność przypisaną w dokumencie Grzegorzowi z Biskupca (von Bischofswerder). Kapelanem i kanclerzem wielkiego mistrza był on w latach 1416-1423, ale po tej dacie również przebywał w siedzibie wielkich mistrzów i określany jako ,alter Kaplan” wypełniał misje dyplomatyczne; formalnie do pełnienia tej funkcji powrócił w 1429 r. Natomiast w latach 1424-1429 kapelanem mistrza i kierownikiem zakonnej kancelarii był brat-kapłan Wawrzyniec (Lorenz); zob. B. Jähnig, Hochmeisterkaplan und Hochmeisterkanzler - die Leiter der Hochmeisterkanzlei in Marienburg 1309-1457, w: Kancelarie krzyżackie. Stan badań i perspektywy badawcze, red. J. Trupinda, Malbork 2002, s. 158-159. Z zestawienia tego wynikałoby, że w omawianym instrumencie notarialnym godność kapelana zastosowano wobec Grzegorza grzecznościowo, względnie w wyniku pewnego skrótu myślowego.

13 ,[...] sigillum prefati reverendi patris domini Johannis episcopi Wladislaviensis [...] in pressula pergameni appendit”; aneks 1.

${ }^{14}$ Die Staatsverträge, nr 164, § 4; K. Neitmann, Die Staatsverträge, s. 192-193.

${ }^{15}$ Dokumenty strony polsko-litewskiej, s. 25-26.

${ }^{16}$ O formularzu instrumentów notarialnych zob. K. Skupieński, Notariat publiczny w średniowiecznej Polsce, Lublin 2002, s. 145-159.

17 Tamże, s. 158. 
obecni archidiakon kurzelowski Jan z Bogucic, notariusz publiczny Jan Trojanowic z Inowrocławia, mieszczanin toruński Piotr Szeliga (Cziras) oraz wikariusz wieczysty katedry włocławskiej - diakon Mikołaj Mikołajewic z Woli. Źródło zamyka standardowa ceduła notarialna z wyrysowanym na początku znakiem notarialnym Stanisława Budkowica z Karnkowa ${ }^{18}$.

Opisana wyżej procedura musiała zostać w jakiś sposób przygotowana. Trzeba było bowiem dostarczyć do Torunia niezwykle cenny dokument traktatowy, tak aby znalazł się tam w przewidzianym czasie. Przygotowania wymagało również bez wątpienia przybycie w odpowiednim momencie polskiej delegacji wraz z notariuszem publicznym. Nie zachowała się jednak żadna korespondencja, która by to odzwierciedlała. Wydaje się wszakże, że osobą odpowiedzialną za dostarczenie dokumentu do Torunia był kapelan Pawła von Rusdorfa, Grzegorz von Bischofswerder, związany z ówczesną wielkomistrzowską kancelarią. Najpewniej to właśnie on odwiózł traktat z powrotem do Malborka. O jego odjeździe i fakcie przywieszenia pieczęci Pelli komtur Marschalk poinformował Rusdorfa w piśmie z 15 IV 1426. Zgodnie $\mathrm{z}$ jego treścią kapelan miał osobiście przedstawić szerszą relację na ten temat. Zakonny urzędnik podał wszakże, że król Władysław przysłał tylko mniejszą pieczęć biskupa ${ }^{19}$.

Pieczęć biskupa Jana dostarczył do Torunia, jak pamiętamy, pasowany rycerz Piotr „Sbiluczsky”. Jego związki z biskupem Janem poświadcza jeszcze dokument Pelli wystawiony w formie instrumentu notarialnego we Włocławku 8 III 1428, gdzie został on wymieniony w liście świadków („Petrus miles, heres de Sbilucicze") jako osoba bezpośrednio poprzedzająca dwóch urzędników biskupiego dworu: marszałka Stanisława z Komorowa i kuchmistrza Jakuba „de Przazna”"20. Dokonując jego identyfikacji, należy, jak się wydaje, wziąć pod uwagę to, że mógł on pochodzić z najbliższego kręgu rodzinnego Pelli, skoro ten nie wahał się powierzyć mu własnej pieczęci. Kierując się ustaleniami Alicji Szymczakowej, pasowanego rycerza Piotra rzeczywiście znajdujemy w interesującym nas okresie w kręgu bratanków biskupa. Pasowanie przed 1424 r. uzyskał bowiem Piotr z Niewiesza, syn wojskiego sieradzkiego Chebdy ${ }^{21}$. Piotr Chebdzic i jego bracia mieli związki majątkowe z wsią Zbylczyce (,Sbiluczicze") w powiecie szadkowskim ${ }^{22}$, od której zdaje się być urobiony przydomek posesjonatywny pasowanego rycerza Piotra, który przywiózł pieczęć biskupa i przywiesił ją pod dokumentem pokojowym (,Sbiluczsky”). Synowie wojskiego Chebdy (wspomniany Piotr oraz Jan, Stanisław, Niklin, Mikołaj i Marcin) w podziale majątkowym dokonanym 23 IV 1428 po śmierci stryja-biskupa (5 kwietnia tr.) ze swoimi braćmi stryjecznymi (synami Stanisława Pelli z Niewiesza) otrzymali bowiem Niewiesz, Kozubów, Łęg, Karnice, Rusinowice i właśnie Zbylczyce ${ }^{23}$. Częścią z tych osad Chebdzice dysponowali jednak już wcześniej. 3 VI 1426, zatem nieco ponad półtora miesiąca po omówionych tu wydarzeniach, Piotr otrzymał od rodzonych w braci w samodzielne użytkowanie wieś Karnice ${ }^{24}$. Nie można zatem wykluczyć, że zgodnie z nieznanymi nam wcześniejszymi regulacjami majątkowymi Niewieskich dzierżył on Zbylczyce, od których urobiono jego przydomek posesjonatywny zastosowany w instrumencie notarialnym Stanisława Budkowica z Karnkowa z 14 IV 1426 oraz w liście świadków dokumentu biskupiego z 8 III 1428, który także spisał w formie instrumentu wspomniany notariusz publiczny ${ }^{25}$.

\footnotetext{
18 Jego opis zob. aneks 1.

19 Aneks 2; A. Szweda, Organizacja, s. 303, 304.

${ }^{20}$ Trzydzieści osiem nie drukowanych oryginałów pergaminowych Archiwum Diec. we Włocławku z pierwszej połowy XV wieku, oprac. i wyd. S. Librowski, ABMK, 56, 1988, nr 18.

${ }^{21}$ A. Szymczakowa, ,Milites strenui” $z$ Sieradzkiego w XV wieku, w: Genealogia. Rola zwiazków rodzinnych i rodowych w życiu publicznym w Polsce średniowiecznej na tle porównawczym, red. A. Radzimiński J. Wroniszewski, Toruń 1996, s. 201, 211; taż, Szlachta sieradzka w XV wieku: magnifici et generosi, Łódź 1998, s. 162-164.

22 S. Zajączkowski, S.M. Zajączkowski, Materiały do słownika geograficzno-historycznego dawnych ziem tęczyckiej i sieradzkiej do 1400 roku, t. 2, Łódź 1970, s. 203.

${ }^{23}$ A. Szymczakowa, Szlachta, s. 163; S. Szybkowski, Biskup włocławski Jan Pella z Niewiesza i jego bratankowie. Z badań nad wpływem duchownych na kariery ich rodzin w późnym średniowieczu, w: Duchowieństwo i laicy, red. A. Wałkówski, Warszawa 2010, 196, 197.

${ }^{24}$ A. Szymczakowa, Szlachta, s. 162.

${ }^{25}$ Trzydzieści osiem, nr 18.
} 
Piotr z Niewiesza i Karnic zapoczątkował linię swej rodziny, która dzierżyła również nabyte przezeń Poddębice w ziemi łęczyckiej. Już za panowania Kazimierza Jagiellończyka awansował na urząd chorążego większego łęczyckiego, który sprawował w latach 1450-1468 ${ }^{26}$.

Wyjaśnienia wymaga jeszcze kwestia, dlaczego biskup włocławski nie przywiesił swojej pieczęci do dokumentu pokojowego przed jego przekazaniem Krzyżakom i tak długo zwlekał z zadośćuczynieniem żądaniom zakonnej korporacji. W przypadku pierwszego z postawionych pytań odpowiedź wydaje się prosta - Pella podczas kompletowania pieczęci gwarantów do głównego dokumentu strony polskiej nie miał jeszcze pieczęci biskupiej. Przekonuje o tym fakt, że jeszcze 7 VI 1423 do dokumentu, w którym tytułował się biskupem włocławskim, przywiesił pieczęć, której typariusz powstał w okresie, kiedy był tylko prepozytem kruszwickim ${ }^{27}$. Najwyraźniej zatem przed majem 1423 r., kiedy w Wielonie doszło do wymiany dokumentów traktatowych, nie sporządzono stosownych tłoków pieczętnych, mimo że Jan papieskie zatwierdzenie uzyskał już jesienią $1421 \mathrm{r}^{28}$

W końcu 1424 r. Pella dysponował już jednak większą pieczęcią biskupią, którą uwierzytelnił list do wielkiego mistrza Pawła von Rusdorfa z 27 grudnia $^{29}$. Typariusz tej pieczęci musiał zatem powstać przed tą datą, tymczasem biskup włocławski jeszcze przez prawie półtora roku zwlekał z przywieszeniem swej pieczęci pod dokumentem pokojowym.

Przyczyna leżała zapewne w złych relacjach pomiędzy nim a stroną krzyżacką. Władze zakonu po śmierci poprzednika Pelli na urzędzie biskupim, księcia opolskiego Jana Kropidły, podjęły zabiegi mające na celu odłączenie od biskupstwa włocławskiego archidiakonatu pomorskiego, stanowiącego większość obszaru diecezji, ewentualnie przeniesienie siedziby biskupiej do Prus. Krzyżacy podjęli w tej kwestii w Kurii Rzymskiej działania, które miały utrudnić Pelli uzyskanie papieskiego zatwierdzenia na biskupstwie włocławskim, byli bowiem przekonani, że nominat króla Władysława Jagiełły przeciwstawi się ich zamiarom. Nowy biskup otrzymał jednak dzięki królewskiemu poparciu papieską konfirmację. Wrogie działania Krzyżaków podjęte wobec niego u progu urzędowania spowodowały, że obie strony nie potrafiły ułożyć przyjaznych relacji i Jan przez cały okres swoich rządów we Włocławku pozostawał w konflikcie z zakonem. Spory dotyczyły dziesięcin należnych Kościołowi kujawskiemu $\mathrm{z}$ archidiakonatu pomorskiego (biskup wystarał się u papieża o ich zamianę $\mathrm{z}$ wiardunkowej na snopową), odszkodowania za spalony w latach wojny 1409-1411 dwór biskupów włocławskich pod Gdańskiem (na Biskupiej Górce) oraz konfliktu z radą Starego Miasta Torunia o czynsze należne z obszarów przypisanych do biskupstwa włocławskiego ${ }^{30}$. Ostrość konfliktu potwierdzają wzajemne opinie o sobie obu stron. Zdaniem strony zakonnej biskup Pella był „bezecny, hardy, złośliwy i skłonny do swarów", Jan z kolei w swoim zeznaniu na procesie polsko-krzyżackim toczonym przed papieskim legatem Antonim Zeno w 1422 r. określił Krzyżaków jako „pyszałków i złoczyńców" "'11. Warto jeszcze dodać, że, jak ustaliła to już dawniej Justyna Bartoszewska, niechęć urzędników zakonnych do biskupa była tak wielka, że prokurator krzyżacki w Kurii, Jan Tiergart, wiedząc o problemach zdrowotnych Jana, w 1428 r. wyrażał nadzieję, że choroba doprowadzi do jego rychłej

${ }^{26}$ Urząd chorążego scedował po 1468, a przed 1470 r. na swego syna Mikołaja, zmarł po 1476 r.; zob. UdR. Spisy, t. 2, z. 1, s. 40, 182; A. Szymczakowa, Szlachta, s. 163, 164.

27 Informacja anonimowego recenzenta wewnętrznego, za którą autorzy pragną mu gorąco podziękować.

28 J. Bieniak, Jan zwany Pełła z Niewiesza h. Pomian, w: Słownik biograficzny Pomorza Nadwiślańskiego, t. 2, red. Z. Nowak, Gdańsk 1994, s. 273.

${ }^{29}$ Geheimes Staatsarchiv Preussischer Kulturbesitz Berlin Dahlem [dalej: GSPK], XX. HA, Ordensbriefarchiv, nr 4365.

${ }^{30}$ Relacje pomiędzy zakonem a Pellą najpełniej omawiają: K. Bieszk, Wielkiego mistrza Michała Küchmeistra zabiegi z r. 1421 o uniezależnienie archidiakonatu pomorskiego od diecezji włocławskiej, Zap. TNT, 7, 1928, s. 291-296, 303-320; J. Bieniak, Jan zwany Pełta, s. 271-275; J. Bartoszewska, Jan Pella z Niewiesza herbu Pomian, biskup włocławski, w świetle korespondencji prokuratora generalnego zakonu krzyżackiego Jana Tiergarta z lat 1421-1428, „Zapiski Kujawsko-Dobrzyńskie”, 15, 2001, s. 103-121; Z. Wilk-Woś, W sprawie sporu o dwór biskupów włocławskich na biskupiej Górce pod Gdańskiem w I połowie XV w., „Gdańskie Studia z Dziejów Średniowiecza”, 9, 2003, s. 312-313.

${ }^{31}$ Lites ac res gestae inter Polonos Ordinemque Cruciferorum. Spory i sprawy pomiędzy Polakami a zakonem krzyżacki. Akta postępowania przed wystannikiem papieskim Antonim Zeno z Mediolanu w latach 1422-1423, wyd. S. Jóźwiak, A. Szweda, S. Szybkowski, Toruń 2015, s. 397; J. Bieniak, Jan zwany Pełła, s. 274. 
śmierci ${ }^{32}$. W tym kontekście rozpatrywać można również fakt przywieszenia do dokumentu pokojowego mniejszej pieczęci biskupa włocławskiego. Jest to symptomatyczne tym bardziej, że jak wskazują zachowane ślady do zamykania i uwierzytelniania korespondencji Pelli z wielkim mistrzem w latach 1424-1426 używana była wspomniana wyżej jego pieczęć większa ${ }^{33}$.

Niechęć biskupa do korporacji krzyżackiej jako przyczynę zwlekania przezeń z uzupełnieniem swojej pieczęci pod dokumentem pokojowym zdaje się sugerować jeszcze jedna przesłanka. Wydaje się bowiem charakterystyczne, że Pella posłał z nią do Torunia swojego nieutytułowanego świeckiego bratanka, dwóch notariuszy publicznych (niebędących jeszcze posiadaczami beneficjów kościelnych), archidiakona z prowincjonalnej kapituły kolegiackiej w Kurzelowie oraz posiadającego tylko święcenia diakońskie wikariusza wieczystego katedry włocławskiej. Zaskakujące jest to, że w delegacji tej nie było żadnego z prałatów i kanoników włocławskich. Można oczywiście podnosić fakt, że Pella wysłał z pieczęcią bratanka jako osobę, do której żywił głębokie zaufanie. Mógł jednak wybrać do tego zadania nie Piotra, ale któregoś z bratanków będących duchownymi - trzech z nich było już prałatami (Jarand, Jan i Niklin), a dwóch kanonikami (Stanisław, Mikołaj) ${ }^{34}$. Trudno także za osoby o wysokiej pozycji uważać prowincjonalnych notariuszy publicznych, których obecność była niezbędna przede wszystkim ze względów technicznych (konieczność sporządzenia instrumentu notarialnego). Wydaje się zatem, że delegacja wysłana z pieczęcią biskupa do Torunia nie miała szczególnie wysokiej rangi. Może to świadczyć, że Jan Pella nie przykładał zbyt wielkiej wagi do zadośćuczynienia krzyżackim żądaniom i w 1426 r. z niechęcią wykonał tylko królewskie polecenie ${ }^{35}$. Perypetie związane z uzupełnieniem jego pieczęci przy dokumencie pokojowym wydają się sugerować, że w krzyżackim przekonaniu o złośliwości i swarliwości Pelli może znajdować się ziarno prawdy. Nie oznaczało to jednak, że biskup bojkotował krzyżacką politykę swego władcy. Widać go bowiem regularnie w składach polskich negocjatorów regulujących kwestie graniczne w latach 1424-1425, zresztą w myśl procedury przewidzianej traktatem mełneńskim ${ }^{36}$.

Długotrwałe zabiegi dotyczące przywieszenia pieczęci biskupiej Jana potwierdzają natomiast, że na jej uzupełnieniu bardzo zależało stronie zakonnej. Wielki mistrz i jego urzędnicy mogli bowiem sądzić, że zadośćuczynienie ich staraniom doprowadzi nie tylko do fizycznego umieszczenia sigillum wpływowego królewskiego doradcy i gwaranta pokoju pod dokumentem traktatowym, ale skłoni również skonfliktowanego z nimi duchownego zarządcę istotnej części ich pruskiego władztwa do okazywania większej ustępliwości. Krzyżackie nadzieje nie spełniły się jednak, wnioskując ze stosunku krzyżackiego prokuratora w Kurii do Jana, wyrażanego w 1428 r.

Starania władz zakonnych o przywieszenie brakujących pieczęci polskich gwarantów do traktatu pokojowego, ewentualnie o wystawienie osobnych dokumentów zatwierdzających postanowienia z $1422 \mathrm{r}$., z drugiej zaś strony żądanie strony polskiej o uzupełnienie pod krzyżackim dokumentem głównym

32 J. Bartoszewska, Jan Pella, s. 124 (Tiergart pisząc swój list do wielkiego mistrza 12 V 1428, nie wiedział, że Pella nie żył już wówczas od ponad miesiąca, zm. 5 IV 1428).

33 GSPK, nr 4365, 4441, 4466, 4471. O pieczęciach Jana Pelli zob. J. Pakulski, Średniowieczne pieczęcie biskupów i kapituły włocławskiej oraz ich symbolika, w: Religijność na Kujawach $i$ w ziemi dobrzyńskiej w czasach staropolskich, red. A. Mietz, Włocławek 2003, s. 57; P. Pokora, Herby na pieczęciach episkopatu doby jagiellońskiej (do końca XV w.), w: Pieczęcie herbowe - herby na pieczeciach, red. W. Drelicharz, Z. Piech, Warszawa 2011, s. 127.

${ }^{34}$ A. Szymczakowa, Szlachta, s. 153, 154, 159, 165, 166.

${ }^{35}$ Za mało prawdopodobną należy uznać możliwość, aby biskup nie realizował krzyżackich żądań, ponieważ aż do 1426 r. nie posiadał typariusza własnej pieczęci mniejszej, a właśnie takie przeważały wśród pieczęci członków episkopatu przywieszonych do polskiego dokumentu głównego pokoju mełneńskiego (Dokumenty strony polsko-litewskiej, s. 24-26, 74), nie sposób bowiem dopatrywać się w tym wypadku jakiegoś bezwzględnie przestrzeganego zwyczaju, skoro biskup płocki Jakub z Kurdwanowa przywiesił tam swoją pieczęć większą (tamże, s. 27). Dodajmy, że mimo zauważalnej dominacji biskupich pieczęci mniejszych na dokumentach traktatowych, w 1411 r. biskup krakowski Piotr Wysz użył swojej pieczęci średniej (A. Szweda, Uwagi o dokumentach rozejmowych i pokojowych z okresu wojny 1409-1411, Zap. Hist., 75, 2010, z. 2, s. 79), a w 1435 r. biskup krakowski Zbigniew Oleśnicki sięgnął po swoją pieczęć większą (Deutschordens-Zentralarchiv, Wiedeń, Urkunden, nr 3359). Nadto, nie wydaje się, aby sporządzenie typariusza jakiejkolwiek pieczęci stanowiło większy problem dla biskupa zamożnej diecezji.

36 A. Szweda, Organizacja, s. 394, 396-397. 
pieczęci arcybiskupa ryskiego i biskupa dorpackiego należy widzieć również w szerszym kontekście. Jak ustalili to już dawniejsi badacze, obie strony zabiegały o pozyskanie w charakterze gwarantów najszerszej reprezentacji społecznej państwa-partnera układu. W przypadku dokumentu głównego strony polskiej doprowadziło to do tego, że w tej roli wystąpiło tam aż 95 osób (obok książąt mazowieckich i litewskich oraz przedstawicieli episkopatu byli to głównie polscy i litewscy urzędnicy ziemscy i terytorialni) oraz 17 rad miejskich - co stanowiło najliczniejsze, jak dotąd, grono gwarantów w dłuższej już historii polsko-krzyżackich porozumień pokojowych. Obok zabiegów krzyżackich pojawienie się w dokumencie traktatu mełneńskiego tak licznych przedstawicieli polskiego stanu szlacheckiego wynikało zapewne również z coraz silniejszej pozycji tej grupy społecznej i jej reprezentacji stanowej zjazdów generalnych (sejmów) ${ }^{37}$. Należy wszakże podkreślić, że również w dokumencie krzyżackim w charakterze gwarantów, obok sześciu biskupów pruskich i inflanckich oraz kilkudziesięciu dostojników krzyżackich różnego szczebla, wystąpiło 18 świeckich rycerzy z Prus i Inflant oraz 19 pruskich miast ${ }^{38}$. Wydaje się to oznaczać, że również we władztwie zakonnym wzięto pod uwagę rosnącą także i tam pozycję stanów.

Przyjęty w latach 1422-1423 sposób pieczętowania głównych dokumentów traktatowych (tłokami pieczętnymi należącymi do gwarantów zgromadzonymi w miejscu spotkania ratyfikacyjnego) nie był rozwiązaniem typowym. Brak pewnych informacji w tym względzie odnośnie do pokoju toruńskiego z 1411 r., jednak - jak wiadomo - po zawarciu 31 XII 1435 pokoju brzeskiego polsko-litewski dokument główny został opieczętowany 4 III 1436 podczas ogólnopolskiego zjazdu w Sieradzu. W przypadku dokumentu zakonnego można stwierdzić, że do Malborka dosyłano odciski pieczęci poszczególnych gwarantów wraz z nićmi służącymi do ich zawieszenia. Jeszcze w początkach maja $1436 \mathrm{r}$. wielki mistrz monitował w tej sprawie radę Głównego Miasta Gdańska. Ratyfikacja poprzez wymianę aktów nastąpiła 1 VIII $1436^{39}$. Natomiast podczas zawierania II pokoju toruńskiego w $1466 \mathrm{r}$. oba dokumenty stron - wstępny i główny - zostały spisane już na miejscu, w Toruniu, w październiku 1466 r., w dokumentach głównych zostawiono tylko miejsce na dopisanie gwarantów, co oczywiste również później dołączono do dokumentów głównych ich pieczęcie - dla strony polskiej wiadomo, że w większości przypadków stało się to na majowym sejmie 1467 r. w Piotrkowie. Gotowe akty wymieniono podczas zjazdu w Elblągu 7 VIII $1467^{40}$. Powyższe przykłady pokazują, że również w tej dziedzinie brak było $\mathrm{w}$ średniowieczu jednego, powszechnie stosowanego wzorca, a rozwiązanie zastosowane w konkretnej sytuacji mogło wynikać z wielu różnych czynników.

${ }^{37}$ Dokumenty strony polsko-litewskiej, s. VIII, 10, 11; A. Gąsiorowski, Polscy gwaranci traktatów z Krzyżakami XIV-XV wieku, „Komunikaty Mazursko-Warmińskie”, 1971, nr 2-3, s. 251, 255; A. Szweda, Organizacja, s. 304.

38 Acten der Ständetage Preussens unter der Herrschaft des Deutschen Ordens, t. 1, wyd. M. Toeppen, Leipzig 1878, s. $410-411$.

39 A. Szweda, Dokumenty pokoju brzeskiego z 31 XII 1435 r. - wprowadzenie do tematu, w: Pabaisko mūšis ir jo epocha. Straipsniu rinkinys, red. I. Vaškevičiūtè, Vilnius 2017, s. 74.

${ }^{40}$ P. Nowak, Dokumenty II pokoju toruńskiego, St. Źródł., 43, 2005, s. 91-92. 


\section{Aneks 1}

Toruń, 14 IV 1426

Instrument notarialny wystawiony przez notariusza autorytetu cesarskiego Stanistawa Budkowica z Karnkowa, opisujący okoliczności przywieszenia do dokumentu głównego pokoju metneńskiego z 1422 r. pieczęci biskupa włoctawskiego Jana [Pelli z Niewiesza]

Oryg.: GSPK, XX. HA, Pergament Urkunden, Schieblade LIII, nr 50, pergamin nierówno przycięty ok. $293 \times 315 \mathrm{~mm}$, in dorso: nota pismem z XV Instrumentum, quod sigillum domini episcopi Wladislaviensis est appensum, stare sygn.: 38, 104, 975, data 1426, pieczęć archiwum królewieckiego z sygnaturą. Reg.: Regesta historico-diplomatica Ordinis S. Mariae Theutonicorum 1198-1525, t. 2, oprac. E. Joachim, wyd. W. Hubatsch, Göttingen 1948, nr 2240.

Uw.: Tekst źródła wydany wedle zasad zawartych w: A. Wolff, Projekt instrukcji wydawniczej dla pisanych źródet historycznych do połowy XVI wieku, St. Źródt., 1, 1957, s. 155-181.

${ }^{a}\|I\| n$ nomine Domini amen. Sub anno nativitatis Eiusdem millesimo quadringentesimo vicesimo sexto, indiccione | quarta, pontificatus sanctissimi in Christo patris et domini nostri, domini Martini divina providencia pape quinti anno | nono, die vero Solis quartadecima mensis Aprilis, hora terciarum vel quasi, in castro Thorunensi Culmensis diocesis, | in mei notarii publici et testium subscriptorum presencia, strennuus dominus Petrus Sbiluczsky ${ }^{1}$, miles serenissimi principis et domini, domini Wladislai regis Polonie ${ }^{2}$ et in negocio appensionis sigilli reverendi in Christo patris et domini, domini Johannis Dei gracia episcopi Wladislauiensis ${ }^{3}$ ad litteras concordie seu contractus et federacionis perpetue pacis inter dictum dominum regem et suum Regnum Polonie ac magnificum et religiosum dominum Paulum Russdorff magistrum generalem ${ }^{4}$ et suos fratres Ordinis Sancte Marie Jerosolomitani Domus Theotunicorum de Prussia facte nunncius per prefatum dominum regem specialis satisfaciendoque promissioni dicti domini regis Polonie, sigillum reverendi in Christo patris, domini Johannis episcopi Wladislauiensis predicti obtulit appendendum die et loco super huiusmodi appensione deputatis, quo oblato venerabiles et religiosi domini Andreas doctor, rector ecclesie parrochialis sancti Johannis in Thorun ${ }^{5}$ ac Gregorius

a Inicjał wysokości około trzech czwartych wysokości kolumny tekstu właściwego instrumentu notarialnego.

${ }^{1}$ Piotr z Niewiesza i Karnic, bratanek biskupa Jana Pelli, zob. tekst główny.

2 Władysław II Jagiełło, król Polski i najwyższy ksiązę Litwy, zm. 1434 (J. Krzyżaniakowa, J. Ochmański, Władysław II Jagietto, Wroctaw 1990).

3 Jan Pella z Niewiesza h. Pomian, prałat i kanonik licznych kapitul, sekretarz królewski, dyplomata króla Władysława Jagietty, wielkorządca krakowski, starosta sandomierski i nowokorczyński 1421, biskup włoctawski 1421-1428 (UdR. Spisy, t. 4, z. 1, s. 294, 301, 314, 350; I. Sulkowska-Kurasiowa, Dokumenty królewskie i ich funkcja w państwie polskim za Andegawenów i pierwszych Jagiellonów 1370-1444, Warszawa 1977, s. 247, 248; J. Bieniak, Jan zwany Pełła z Niewiesza h. Pomian, w: Stownik biograficzny Pomorza Nadwiślańskiego, t. 2, red. Z. Nowak, Gdańsk 1994, s. 271-275; A. Szymczakowa, Szlachta sieradzka w XV wieku: magnifici et generosi, Łódź 1998, s. 150-152; A. Szweda, Organizacja i technika dyplomacji polskiej $w$ stosunkach z zakonem krzyżackim w Prusach w latach 1386-1454, Toruń 2009, wg indeksu).

${ }^{4}$ Pawet von Rusdorf, prokurator kętrzyński 1412, komtur tucholski 1413-1414, wójt papowski i lipieniecki 1413-1414, podskarbi zakonu krzyżackiego 1414-1415, komtur gniewski 1416, wielki komtur 1416-1418, wielki szatny 1415-1416, 1418-1422, równocześnie komtur dzierzgoński 1418-1422, wielki mistrz zakonu krzyżackiego 1422-1441 (C.A. Lückerath, Paul von Rusdorf. Hochmeister des Deutschen Ordens 1422-1441, Bad Godesberg 1969; B. Jähnig, Dostojnicy zakonu krzyżackiego w Prusach, w: Zakon krzyżacki w Prusach i Inflantach. Podziały administracyjne i kościelne w XIII-XVI wieku, red. R. Czaja, A. Radzimiński, Toruń 2013, s. 290, 292, 294, 295, 303, 315, 318).

${ }_{5}^{5}$ Andrzej (Andreas) Pfaffendorf, ksiądz krzyżacki, bakałarz sztuk Uniwersytetu Praskiego 1405, student Uniwersytetu Wiedeńskiego 1417, doktor prawa kanonicznego na Uniwersytecie Bolońskim 1421, pleban kościoła św. Janów w Starym Mieście Toruniu 1425-1433, pleban kościoła NMP w Głównym Mieście Gdańsku 1437, zm. 1437 (Altpreussische Biographie, t. 2, red. Ch. Krollmann, Marburg 1967, s. 498-499; B. Jähnig, Andreas Pfaffendorf OT. Pfarrer der Altstadt Thorn (1425-1433), „Beiträge zur Geschichte Westpreussens”, 7, 1981, s. 161-187). 
cappellanus magnifici et religiosi domini Pauli magistri generalis ${ }^{6}$ ac Henricus Marschalk comendator Thorunensis ${ }^{7}$ easdem litteras concordie seu contractus ac federacionis pacis coram prefato domino Petro Sbiluczsky, milite et nunncio, produxerunt, quibusquidam litteris ipse dominus Petrus Sbiluczsky sigillum prefati reverendi patris domini Johannis episcopi Wladislauiensis, intus de cera rubea et ab extra naturali seu glauca, in pressula pergameni appendit, in cuius sigilli medio a parte sinistra infula et a dextra parte baculus pontificalis, que angelus in superficie eiusdem sigilli tenere videbatur, sub quibus in clipeo caput bubali et inter aures huiusmodi capitis gladius sculptus apparebat. Littere autem circumferenciales in huiusmodi sigillo scripte taliter legebantur: „S. iohannis episcopi wladislauiensis”. Super appensione autem huiusmodi sigilli et eius caracteribus, ipsis diligenter visis et inspectis, prout sunt scripta, prefati domini, tam Petrus Sbiluczsky miles, quam Andreas doctor, Gregorius capellanus et Henricus commendator a me notario publico subscripto unum vel plura petierunt sibi fieri et confici publicum seu publica intrumentum seu instrumenta. Acta sunt hec anno, indiccione, pontificatus, die, mense, hora et loco, quibus supra, presentibus ibidem honorabilibus et discretis viris, dominis Johanne archidiacono ecclesie collegiate Cureleowiensis $[s]$ Gneznensis diocesis ${ }^{8}$, Johanne Troyani de Juueniwladislauia notario publico ${ }^{9}$, Petro Scheliga cive de Thorun ${ }^{10}$, Nicolao Nicolai de Wola diacono ${ }^{11}$, vicario perpetuo in ecclesia Wladislauiensi et quampluribus fidedignis testibus circa premissa.

Z.N. ${ }^{\mathrm{b}}{ }^{\mathrm{E}}$ Elt ego Stanislaus Budconis de Carncowo clericus Plocensis diocesis, | publicus imperiali auctoritate notarius ${ }^{12}$, quia predicti sigilli reverendi patris, | domini Johannis episcopi Wladislaviensis ad litteras concordie ac contractus et $\mid$ federacionis pacis perpetue per dominum Petrum Sbiluczsky

\footnotetext{
${ }^{b}$ Sześciolistny kwiat na trzech gradusach.

c Inicjał wysokości około czterech wersów kolumny tekstu.
}

${ }^{6}$ Grzegorz z Biskupca (von Bischofswerder), kapelan i kanclerz wielkich mistrzów zakonu krzyżackiego Michała Küchmeistra i Pawła von Rusdorfa (1416-1423, 1429-1431), zm. 1431 (B. Jähnig, Hochmeisterkaplan und Hochmeisterkanzler - die Leiter der Hochmeisterkanzlei in Marienberg 1309-1457, w: Kancelarie krzyżackie. Stan badań i perspektywy badawcze, red. J. Trupinda, Malbork 2002, s. 158).

7 Henryk Marschalk, petniacy obowiązi wójta bratiańskiego 1410-1411, komtur kowalewski 1413-1415, komtur domowy królewiecki 1418-1421, wójt biskupa sambijskiego 1421-1423, wójt tczewski 1424, komtur toruński 1424-1428, komtur świecki 1430-1434, prokurator papowski 1435, komtur radzyński 1436-1438 (B. Jähnig, Dostojnicy, s. 293, 309, 310, 313, 315, 321).

${ }^{8}$ Jan z Bogucic (powiat szadkowski) h. Szeliga, syn kasztelana konarskiego tęczyckiego Stanisława z Byczyny i Bogucic, uczestnik wojny polsko-krzyżackiej 1422, archidiakon kurzelowski 1426 (w 1427 na mocy decyzji papieskiej utracit wszystkie prawa do tego beneficjum na rzecz Janusza Włodkowica zw. W'scieklica z Czarncy, który wkrótce realnie je objąt), kanonik włocławski 1435-1468 (prowizja papieska 1430), pleban w Górze (Bull. Pol, t. 4, nr 1873, 2477; t. 5, nr 281, 382; UdR. Spisy, t. 2, z. 1, s. 47, 161; S. Zajączkowski, S.M. Zajaczkowski, Materiaty do stownika geograficzno-historycznego dawnych ziem tęczyckiej i sieradzkiej do 1400 roku, t. 1, Łódź 1966, s. 20; A. Radzimiński, „...super irregularitate, si quam propterea incurrit”. Dyspensy ,ex defectu perfectae lenitatis” duchowieństwa w okresie pontyfikatu Marcina V, w: Venerabiles, nobiles et honesti. Studia z dziejów spoleczeństwa Polski średniowiecznej, red. A. Radzimiński, A. Supruniuk, J. Wroniszewski, Toruń 1997, s. 118-119; A. Gasiorowski, Kanonicy włocławscy w najstarszej metryce kapitulnej (1435-1500), w: Duchowieństwo kapitulne w Polsce średniowiecznej i wczesnonowożytnej. Pochodzenie i funkcjonowanie elity kościelnej, red. A. Radzimiński, Toruń 2000, s. 41).

${ }^{9}$ Bliżej nieznany.

${ }_{10}$ Piotr Szeliga (Cziras) h. Szeliga, mieszczanin toruński pochodzacy z polskiej rodziny szlacheckiej, tawnik Starego Miasta Torunia, rajca Starego Miasta Torunia 1409-1411, zm. 1431 (W. Szczuczko, Cziras Piotr h. Szeliga, w: Stownik biograficzny Pomorza Nadwiślańskiego, t. 1, red. S. Gierszewski, Gdańsk 1992, s. 281, 282; R. Czaja, Urzędnicy miejscy Torunia. Spisy, t. 1: Do roku 1454, Toruń 1999, s. 94-96, 138, 198; K. Mikulski, Szlachcic w mieście, czyli kariera rodziny Szeligów alias Czirasów w Toruniu, „Rocznik Łódzki”, 61, 2014, s. 59-67).

${ }^{11}$ Bliżej nieznany, możliwe jednak, że tożsamy z wikariuszem wieczystym katedry włocławskiej Mikołajem Mikołajewicem z Wasewa, wystęujacym w latach 1427-1430 (Bull. Pol., t. 4, nr 2000, 2295, 2340, 2345, 2479).

12 Stanistaw Budkowic z Karnkowa (ziemia dobrzyńska), zapewne h. Junosza, student Uniwersytetu Krakowskiego 1400, notariusz publiczny autorytetu cesarskiego aktywny na terenie diecezji włocławskiej i płockiej, archidiakon kruszwicki 1439, zm. przed 1441 (KDPol., t. 2/1, nr 344, 377; KDWlkp., t. 5, nr 74; Zbiór dokumentów i listów miasta Płocka, t. 1, wyd. S.M. Szacherska, Warszawa 1975, $n r$ 86, 87; Bull. Pol., t. 5, nr 970; Trzydzieści osiem nie drukowanych oryginałów pergaminowych Archiwum Diec. we Włocławku z pierwszej połowy XV wieku, oprac. i wyd. S. Librowski, ABMK, 56, 1988, nr 11, 18, 25, 32; Metryka Uniwersytetu Krakowskiego z lat 1400-1508, wyd. A. Gąsiorowski, T. Jurek, I. Skierska, Kraków 2004, t. 1, s. 45, t. 2, s. 205). 
militem appensioni aliisque omnibus et singulis premissis, dum sic, ut premittitur, fierent et agerentur, una cum prenominatis testibus presens interfui, eaque omnia et singula sic fieri vidi et audivi, ideo presens publicum instrumentum ${ }^{\mathrm{d}}$ super appensione huiusmodi sigilli manu propria confeci et scripsi, signo et nomine meis solitis consuetis consignando in fidem et testimonium omnium et singulorum premissorum rogatus et requisitus.

d Brak w oryg. 


\section{Aneks 2}

Stary Toruń, 15 IV 1426

Komtur toruński [Henryk Marschalk] do wielkiego mistrza [Pawła von Rusdorfa]: informuje o odjeździe Grzegorza [z Biskupca], który ustnie przedstawi okoliczności przywieszenia pieczęci biskupa włocławskiego [do dokumentu traktatu metneńskiego], o śmierci wojewody kujawskiego [inowrockawskiego] Janusza [z Kościelca], planowanym zjeździe pod Jasińcem i o itinerarium króla Władysława Jagietly

Oryg.: GSPK, XX. HA, Ordensbriefarchiv, $n r$ 4571, papier, 31 x 22,2 mm, ślady po pieczęci o średnicy $37 \mathrm{~mm}$ zamykajacej list, ślady po zgięciach, in dorso: adnotacja kancelarii zakonnej: Marschalk; adres z klauzula pośpieszności: Dem erenwirdigen unserm homeister mit aller wirdikeith tag und nacht an alles seume, grose macht doran leiet oraz noty pocztowe: Gegangen von |-th-| Aldenthorun am montage nach Misericordia Domini nachmittage hora decima; Gegangen von Papaw am dinstage dornach hora IIII ${ }^{\text {a }}$ vormittage; Gegangen von Grudencz am selbige tage hora IX ${ }^{\mathrm{a}}$ vormittage; Gegangen von Roghwsin am selbige tage hora $|-\mathrm{XII}-|$ prima nochmittage.

Reg.: Regesta historico-diplomatica Ordinis S. Mariae Theutonicorum 1198-1525, t. 1, cz. 1, oprac. E. Joachim, wyd. W. Hubatsch, Göttingen 1948, nr 4571.

Uw.: W edycji uwzględniono D. Heckmann, Leitfaden zur Edition deutschsprachigen Quellen (13.-16. Jahrhundert), „Preussenland”, 3, 2012, s. 7-13, zachowując jednak spójność obu aneksów.

Meinen gar willigen, underthenigen gehorsam czu allen geczeiten czuvor. Erenwirdigen, gnediger, liber | her meister'! Uwir gnade geruche czu wissen, das her Gregor $^{2}$ also heute von mir gescheiden ist | czu Thorun, der uwir gnade wol muntlich undirrichten wirt, wie die zachen entscheiden seyn, wenne | der herre ko $^{\mathrm{e}}$ nig $^{3}$ des herren bisschofes von Leslow ${ }^{4}$ clein ingsegel hatte her gesant und hat das laszen anhengen, als euch her Gregor ouch wol muntlich undirrichten wirt. Gnediger liber her meister! So hat mir Petrassche ${ }^{5}$ enpoten in gebunge desis brives, das her Hannus von Dabren der woywode uff der Koyen ${ }^{6}$ als hewte tot ist nachmittage und seine knechte etliche czu Thorun sein und koufen, was man dorczu darff. Gnediger liber her meister! Als mir uwir gnade geschreben hat von dem tage czum Jesnicz ${ }^{7}$, do wil ich mich czu schicken mit dem pharer $^{8}$ und wellen den tag do |-selbist-|a halden ${ }^{b-n a c h}$ uwir befelunge- ${ }^{-b}$. Was zich denne do vorloufen wirt und anders, das do notdurftig ist, das wil ich euch unvorczogen schreiben. Ouch alz ir mir geschreben hat von dem herren ko nige, do wil ich fleisige achtunge uff haben, wenne ich vorneme, das her bis suntag kommt kein Ploczkow, als ich uwirn gnaden vor geschreben habe, und fordan kein Thorun obir ${ }^{c}$ nicht kommt bey acht ader czehen tagen ${ }^{9}$. Gegeben czu Aldenthorun am montage nach Misericordia Domini im XIIII ${ }^{\mathrm{C}}$ und XXVI jare.

Kompthur czu Thorun ${ }^{10}$

\footnotetext{
${ }^{a}$ Wyraz skreślony.

${ }^{b-b}$ Dopisane poniżej przy znaku odnośnika.

c Wyraz nadpisany.

${ }^{1}$ Zob. aneks 1, przyp. 4.

2 Zob. aneks 1, przyp. 6.

${ }^{3}$ Zob. aneks 1, przyp. 2.

${ }_{4}$ Zob. aneks 1, przyp. 3.

5 Zob. aneks 1, przyp. 10.

${ }^{6}$ Janusz z Kościelca, kasztelan dobrzyński z nominacji wielkiego mistrza zakonu krzyżackiego Konrada von Jungingena, wojewoda inowrocławski 1412-1426, starosta dobrzyński 1418-1421 (UdR. Spisy, t. 6, z. 1, s. 91, 209, 163, 261, 295, 305).

${ }^{7}$ O zjeździe pod Jasińcem zob. A. Szweda, Organizacja i technika dyplomacji polskiej w stosunkach z zakonem krzyżackim w Prusach w latach 1386-1454, Toruń 2009, s. 399.

${ }^{8}$ Zob. aneks 1, przyp. 5.

9 Informacje zgodne ze znanym itinerarium królewskim: A. Gąsiorowski, Itinerarium króla Władysława Jagietly 1386-1434, wyd. 2, Warszawa 2015, s. 107.

${ }_{10}$ Zob. aneks 1, przyp. 7.
} 


\title{
A few words on the seal of bishop of Włoclawek Jan Pella of Niewiesz on the document of Melno Peace of 1422
}

\begin{abstract}
Summary: The purpose of the article is to present trials and tribulations with the attachment of the seal of Bishop of Włocławek Jan Pella of Niewiesz to the main Polish document of the 1422 Melno Peace. Despite the fact that the sealed document of the treaty was handed over to the Teutonic Knights at an assembly at Wielona in April of 1423, there was no seal of Bishop Jan, who was one of the Polish guarantors of the peace. It was not until 14 April 1426 that the seal was put to the document as a result of the agreements made at a Polish-Teutonic meeting at Grodno in December 1425. The bishop's seal was brought to Torun by a delegation made up of Jan Pella's nephew, Piotr of Niewiesz, and a few low-ranking clergymen. The actual attachment of the seal to the document especially provided for this occasion was made by the bishop's nephew, and the seal was described in great detail in a notary's instrument issued for this reason. The article is supplemented by an appendix in the form of edition of two sources related to the attachment of the bishop's seal, that is the notary's instrument of 14 April, and a letter of Torun Commander Henryk Marschalk to the Grand Master of the Teutonic Order Paul von Rusdorf of 15 April 1426.
\end{abstract}

\section{Notki o Autorach:}

Dr hab. Adam Szweda, profesor nadzwyczajny w Zakładzie Nauk Pomocniczych Historii Instytutu Historii i Archiwistyki Uniwersytetu Mikołaja Kopernika w Toruniu. Specjalizuje się w historii dyplomacji średniowiecznej, dziejach stosunków polsko-krzyżackich, dyplomatyce oraz edytorstwie pisanych źródeł historycznych.

Dr hab. Sobiesław Szybkowski, profesor nadzwyczajny w Zakładzie Historii Średniowiecza Polski i Nauk Pomocniczych Historii Instytutu Historii Uniwersytetu Gdańskiego. Specjalizuje się w dziejach politycznych Polski i Wielkiego Księstwa Litewskiego w późnym średniowieczu, genealogii i prozopografii polskiej szlachty późnośredniowiecznej, historii społecznej oraz edytorstwie pisanych źródeł historycznych.

\author{
Authors: \\ Adam Szweda \\ Instytut Historii i Archiwistyki UMK \\ ul. Władysława Bojarskiego 1 \\ 87-100 Toruń \\ e-mail: aszweda@umk.pl \\ Sobiesław Szybkowski \\ Instytut Historii Uniwersytetu Gdańskiego \\ ul. Wita Stwosza 55 \\ 80-308 Gdańsk \\ e-mail: s.szybkowski@ug.edu.pl
}

Adam Szweda, dr hab., associate professor at the Department of Auxiliary Sciences of History at the Institute of History and Archival Studies of Nicolaus Copernicus University in Torun. He specialises in the history of medieval diplomacy, Polish-Teutonic relations, studies of diplomacy, and editing of written historical sources.

Sobiesław Szybkowski, dr hab., associate professor at the Department of Medieval History of Poland and Auxiliary Sciences of History at the Institute of History of the University of Gdańsk. He specialises in the political history of Poland and the Grand Duchy of Lithuania in the Late Middle Ages, genealogy and prosopography of late-medieval Polish nobility, social history and editing of written historical sources.

\section{Bibliografia}

\section{Źródła}

Acten der Ständetage Preussens unter der Herrschaft des Deutschen Ordens, t. 1, wyd. M. Toeppen, Leipzig 1878 Bullarium Poloniae, t. 4-5, wyd. I. Sułkowska-Kurasiowa, S. Kuraś, M. Kowalczyk, A. i H. Wajs, Roma-Lublin 1992-1995 
Codex diplomaticus Regni Poloniae et Magni Ducatus Lithuaniae, t. 4, wyd. M. Dogiel, Wolno 1764

Dokumenty strony polsko-litewskiej pokoju metneńskiego z 1422 roku, wyd. P. Nowak, P. Pokora, Poznań 2004

Kodeks dyplomatyczny Polski, t. 2/1, wyd. L. Rzyszczewski, A. Muczkowski, Warszawa 1848

Kodeks dyplomatyczny Wielkopolski, t. 5, wyd. F. Piekosiński, Poznań 1908

Lites ac res gestae inter Polonos Ordinemque Cruciferorum. Spory i sprawy pomiędzy Polakami a zakonem krzyżacki. Akta postępowania przed wystannikiem papieskim Antonim Zeno z Mediolanu w latach 1422-1423, wyd. S. Jóźwiak, A. Szweda, S. Szybkowski, Toruń 2015

Metryka Uniwersytetu Krakowskiego z lat 1400-1508, t. 1-2, wyd. A. Gąsiorowski, T. Jurek, I. Skierska, Kraków 2004

Regesta historico-diplomatica Ordinis S. Mariae Theutonicorum 1198-1525, t. 1/1, 2, oprac. E. Joachim, wyd. W. Hubatsch, Göttingen 1948

Die Staatsverträge des Deutschen Ordens in Preußen im 15. Jahrhundert, t. 1, wyd. E. Weise, wyd. 2, Marburg 1970

Trzydzieści osiem nie drukowanych oryginałów pergaminowych Archiwum Diec. we Włoctawku z pierwszej połowy $X V$ wieku, oprac. i wyd. S. Librowski, ABMK, 56, 1988, s. 189-309

Zbiór dokumentów i listów miasta Płocka, t. 1, wyd. S.M. Szacherska, Warszawa 1975

\section{Opracowania}

Altpreussische Biographie, t. 2, red. Ch. Krollmann, Marburg 1967

Bartoszewska J., Jan Pella z Niewiesza herbu Pomian, biskup włocławski, w świetle korespondencji prokuratora generalnego zakonu krzyżackiego Jana Tiergarta z lat 1421-1428, „Zapiski Kujawsko-Dobrzyńskie”, 15, 2001, s. 103-121

Bieniak J., Jan zwany Petta z Niewiesza h. Pomian, w: Stownik biograficzny Pomorza Nadwiślańskiego, t. 2, red. Z. Nowak, Gdańsk 1994, s. 271-275

Bieszk K., Wielkiego mistrza Michała Küchmeistra zabiegi z r. 1421 o uniezależnienie archidiakonatu pomorskiego od diecezji wloctawskiej, Zap. TNT, 7, 1928, s. 291-296, 303-320

Czaja R., Urzędnicy miejscy Torunia. Spisy, t. 1: Do roku 1454, Toruń 1999

Gąsiorowski A., Arcybiskupi gnieźnieńscy w Polsce pierwszych Jagiellonów, Rocz. Hist., 59, 1993, s. 93-111

Gąsiorowski A., Itinerarium króla Władystawa Jagietty 1386-1434, wyd. 2, Warszawa 2015

Gąsiorowski A., Kanonicy włocławscy w najstarszej metryce kapitulnej (1435-1500), w: Duchowieństwo kapitulne w Polsce średniowiecznej $i$ wczesnonowożytnej. Pochodzenie i funkcjonowanie elity kościelnej, red. A. Radzimiński, Toruń 2000, s. 9-51

Gąsiorowski A., Polscy gwaranci traktatów z Krzyżakami XIV-XV wieku, „Komunikaty Mazursko-Warmińskie”, 1971, nr 2-3, s. 245-265

Heckmann D., Leitfaden zur Edition deutschsprachigen Quellen (13.-16. Jahrhundert), „Preussenland”, 3, 2012, s. $7-13$

Jähnig B., Andreas Pfaffendorf OT. Pfarrer der Altstadt Thorn (1425-1433), „Beiträge zur Geschichte Westpreussens”, 7, 1981, s. 161-187

Jähnig B., Dostojnicy zakonu krzyżackiego w Prusach, w: Zakon krzyżacki w Prusach i Inflantach. Podziały administracyjne i kościelne w XIII-XVI wieku, red. R. Czaja, A. Radzimiński, Toruń 2013, s. 279-357

Jähnig B., Hochmeisterkaplan und Hochmeisterkanzler - die Leiter der Hochmeisterkanzlei in Marienberg 1309_ -1457, w: Kancelarie krzyżackie. Stan badań i perspektywy badawcze, red. J. Trupinda, Malbork 2002, s. 149-166

Krzyżaniakowa J., Ochmański J., Władysław II Jagiełto, Wrocław 1990

Lichończak-Nurek G., Wojciech herbu Jastrzębiec, arcybiskup i mąż stanu (ok. 1362-1436), Kraków 1996

Lückerath C.A., Paul von Rusdorf. Hochmeister des Deutschen Ordens 1422-1441, Bad Godesberg 1969

Mikulski K., Szlachcic w mieście, czuli kariera rodziny Szeligów alias Czirasów w Toruniu, „Rocznik Łódzki”, 61, 2014, s. 59-67

Neitmann K., Die Staatsverträge des Deutschen Ordens in Preussen 1230-1449. Studien zur Diplomatie eines spätmittelalterlichen deutschen Teritorialstaates, Köln-Wien 1986

Nowak P., Dokumenty II pokoju toruńskiego, St. Źródł., 43, 2005, s. 85-110.

Pakulski J., Średniowieczne pieczęcie biskupów i kapituły włocławskiej oraz ich symbolika, w: Religijność na Kujawach $i$ w ziemi dobrzyńskiej w czasach staropolskich, red. A. Mietz, Włocławek 2003, s. 45-77

Pokora P., Herby na pieczęciach episkopatu doby jagiellońskiej (do końca XV w.), w: Pieczęcie herbowe - herby na pieczęciach, red. W. Drelicharz, Z. Piech, Warszawa 2011, s. 109-190

Radzimiński A., ,....super irregularitate, si quam propterea incurrit”. Dyspensy ,, ex defectu perfectae lenitatis" duchowieństwa w okresie pontyfikatu Marcina V, w: Venerabiles, nobiles et honesti. Studia z dziejów 
społeczeństwa Polski średniowiecznej, red. A. Radzimiński, A. Supruniuk, J. Wroniszewski, Toruń 1997, s. $115-124$

Skupieński K., Notariat publiczny w średniowiecznej Polsce, Lublin 2002

Sperka A., Zmiany na arcybiskupstwie gnieźnieńskim, biskupstwie krakowskim i urzędach kancelaryjnych na przetomie 1422/1423 roku, „Teki Krakowskie”, 5, 1997, s. 139-146

Sułkowska-Kurasiowa I., Dokumenty królewskie i ich funkcja w państwie polskim za Andegawenów i pierwszych Jagiellonów 1370-1444, Warszawa 1977

Szczuczko W., Cziras Piotr h. Szeliga, w: Stownik biograficzny Pomorza Nadwiślańskiego, t. 1, red. S. Gierszewski, Gdańsk 1992, s. 281-282

Szweda A., Dokumenty pokoju brzeskiego z 31 XII 1435 r. - wprowadzenie do tematu, w: Pabaisko mūšis ir jo epocha. Straipsniu rinkinys, red. I. Vaškevičiūte, Vilnius 2017, s. 69-90

Szweda A., Organizacja i technika dyplomacji polskiej w stosunkach z zakonem krzyżackim w Prusach $w$ latach 1386-1454, Toruń 2009

Szweda A., Uwagi o dokumentach rozejmowych i pokojowych z okresu wojny 1409-1411, Zap. Hist., 75, 2010, z. 2, s. 67-85

Szybkowski S., Biskup włocławski Jan Pella z Niewiesza i jego bratankowie. Z badań nad wpływem duchownych na kariery ich rodzin w późnym średniowieczu, w: Duchowieństwo i laicy, red. A. Wałkówski, Warszawa 2010, s. 190-205

Szymczakowa A., , Milites strenui” z Sieradzkiego w XV wieku, w: Genealogia, Rola zwiazków rodzinnych i rodowych $w$ życiu publicznym w Polsce średniowiecznej na tle porównawczym, red. A. Radzimiński J. Wroniszewski, Toruń 1996, s. 191-214

Szymczakowa A., Szlachta sieradzka w XV wieku: magnifici et generosi, Łódź 1998

Urzędnicy kujawscy i dobrzyńscy XII-XV wieku. Spisy, oprac. J. Bieniak, S. Szybkowski, Urzędnicy dawnej Rzeczypospolitej XII-XVIII wieku. Spisy, t. 6, z. 1, Kórnik 2014

Urzędnicy łęczyccy, sieradzcy $i$ wieluńscy XIII-XV wieku. Spisy, oprac. J. Bieniak, A. Szymczakowa, Urzędnicy dawnej Rzeczypospolitej XII-XVIII wieku. Spisy, t. 2, z. 1, Wrocław 1985

Urzędnicy małopolscy XII-XV wieku. Spisy, oprac. J. Kurtyka, T. Nowakowski, F. Sikora, A. Sochacka, P.K. Wojciechowski, B. Wyrozumska, Urzędnicy dawnej Rzeczypospolitej XII-XVIII wieku. Spisy, t. 4, z. 1, Wrocław 1990

Wilk-Woś Z., W sprawie sporu o dwór biskupów włocławskich na biskupiej Górce pod Gdańskiem w I połowie $X V$ w., „Gdańskie Studia z Dziejów Średniowiecza”, 9, 2003, s. 309-320

Wolff A., Projekt instrukcji wydawniczej dla pisanych źródeł historycznych do połowy XVI wieku, St. Źródł., 1, 1957, s. $155-181$

Zajączkowski S., Zajączkowski S.M., Materiały do słownika geograficzno-historycznego dawnych ziem łęczyckiej i sieradzkiej do 1400 roku, t. 1-2, Łódź 1966-1970 